\title{
An Elucidation of School Administration and Work Culture of Schools in Relation to Teacher's Satisfaction
}

Uma Sheokand*

Panjab University, Chandigarh, India

\begin{abstract}
In order to manage particular organization, administration is required. Administration and work culture of any organisation is the comprehensive effort to direct, guide and to integrate associated human strivings which are focused towards some specific ends or aim. In the era of globalization, when the organizations are going through a tremendous change; schools are no exception and teachers are the most cardinal actors in the entire educational endeavour Academic excellence of schools is largely indicative of the performance level of the respective teaching faculty. Teachers who used to occupy a very high position in ancient India, unfortunately, today, there image appears to be dismal. Improving the professional satisfaction as well as work engagement among teachers has become important issues on the agenda of upliftment of primary education in the nation. In addition to this, in order to attain educational goals, there is a dire need to ascertain the job satisfaction of teachers. Analytical approach undertaking work culture that includes psychological, social, economical and administrative aspect of the problem, is necessary to understand and to resolve the issues of teachers. Hence, this study attempted to get a comprehensive picture of current administrative and organisational satisfaction of teachers. This study also endeavoured to make a comparative study of satisfaction of government and private school teachers' towards organisational administration and work culture therein. Undemocratic principal's behaviour, uncooperative colleagues and administrative staff, teacher's job insecurity, faulty communication, biased recruitments, job insecurities, lack of promotion opportunities, give rise to teachers' dissatisfaction towards administration and organisation as a whole. Participative decision making, recruitments and promotion based on capability of a teachers and above all respect to the profession can open the gate way to more efficient people to adopt teaching profession and to achieve long cherished educational goals
\end{abstract}

Keywords: School administration; Primary education; Educational growth; Condition of teachers

\section{Introduction}

Administration is to get things done for the accomplishment of some desired objectives. "Administration is comprehensive effort to direct, guide and integrates associated human strivings which are focussed towards specific ends or aims. Administration is conceived as the necessary activities of those individuals (executives) in an organisation who are charged with ordering, forwarding and facilitating the associated efforts of a group of individuals brought together to realize certain defined purposes" [1].

In ancient Indian education system Brahmin gurus used to offer education to the students. But, now in the globalised world education has also come under the administration as in form of education administration. "Education, administration is closely related to superintendence, supervision, planning, oversight, direction, organization, control, guidance, and regulation" [2]. Educational managers are required to administer educational institutions. Educational administration approaches statesmanship when there are clearly formulated long term policies and objectives, and when dayby-day activities and problems are dealt with under the guidance of the perspective given by such long-term policies" [3]. Paul defined educational administration as, 'the influencing of one group of human beings, the pupils, to grow towards defined objectives; utilizing a second group of human beings, the teachers as agents; and operating in a setting of a third group of human beings, the public, variously concerned both with objectives and with means used to achieve them" [4].

\section{Organisational culture and job satisfaction}

In order to understand modern organisation, it is essential to analyse and interpret this "within organisation environment" reflected in the climate of the organisation. Social interaction, inter-personal relationships, socio-emotional climate, or psychological environment formulate organisational culture [5]. This organisational culture of school also, directly or indirectly impact on its employee's satisfaction towards organisation, whether they are teachers or other staff. Organisational work culture should be managed in such a way that besides achieving organizational goals and objectives, it must provide job satisfaction to its employees in a non-discriminatory, affirmative, and effective manner [6]. Because highly satisfied employees tend to have better physical, mental health; and it also results in lesser work grievances in organisation [7]. Employees with high job satisfaction are highly motivated towards their work and are more enthusiastic in performing the given tasks. It creates a feeling of belongingness, a sense of pride and spirit to make efforts to accomplish and maintaining an organizational ambience [8]. Moreover, employees with high job satisfaction learn the new job-related tasks easily, thus have less job stress and unrest. Satisfied employees are more likely to be committed to their organizations and exhibit higher levels of performance and productivity [9-10]. Organisational culture differs from organisation to organisation. Still there are certain factors that determine satisfaction of its staff. These factors not only impact employees on the level of dedication, commitment and belongingness towards organisation but also influence on overall efficiency and productivity of the organisation.

An educational institution can be easily conceptualized, in this background, as an organisation or a social system constructed to attain

*Corresponding author: Uma Sheokand, Panjab University, Chandigarh, India, Tel: 1800-180-2065; E-mail: umasheokand15@gmail.com

Received June 08, 2017; Accepted June 29, 2017; Published July 01, 2017

Citation: Sheokand U (2017) An Elucidation of School Administration and Work Culture of Schools in Relation to Teacher's Satisfaction. Review Pub Administration Manag 5: 217. doi:10.4172/2315-7844.1000217

Copyright: (c) 2017 Sheokand U. This is an open-access article distributed under the terms of the Creative Commons Attribution License, which permits unrestricted use, distribution, and reproduction in any medium, provided the original author and source are credited. 
certain specific goals and teachers are the most strategic weapons to attain those goals. Job satisfaction of teachers is inevitable to achieve the objectives of education goals.

Job satisfaction is multidimensional psychological response to one's job [11]. Various administrative and organisational factors are directly associated with job satisfaction of employees as job satisfaction is a feeling which can be explained in simple words as the extent to which an individual is satisfied with his or her job. Hoppock defined job satisfaction as "any combination of psychological, physiological, and environmental circumstances that causes a person truthfully to say, 'I am satisfied with my job" [12]. Hence, it is positive attitude or feeling towards organisation and related aspects of job. According to Locke, job satisfaction is a "pleasurable or positive emotional state of one's job or job experience" [13]. Andrew described that it as is the "amount of pleasure or contentment associated with a job" [14]. Graham defined job satisfaction as "the measurement of one's total feelings and attitudes towards one's job" [15]. Thus, job satisfaction is a comprehensive reaction towards various factors. Some of those factors considered under this study are as follows:

\section{Work culture in School}

2. Perception of teachers regarding principal's behaviour

3. Behaviour of colleagues/ co-worker

4. Behaviour of administrative staff in school

5. Recognition in school

6. Job security

7. Proneness of teacher to leave the teaching job

8. Teachers' perception regarding their salaries

9. Communication in school

10. Participation of teachers in decision making

11. Recruitments process

12. Teacher's promotion

\section{Objective}

The objective of the subject matter is to make comparative analysis of job satisfaction of government and private primary school teachers.

\section{Methodology}

The study would employ the following research methodology

\section{Sample selection}

The various administrative Blocks of Kaithal District as per the statistical and economic survey of Haryana can be ranked on different literacy levels. The same may be perused from Table 1 .

Three Blocks viz. Pundri, Kaithal and Kalayat representing highest, middle and lowest in the literacy level have been selected as strata of sample (Statistical and Economic Survey of Haryana, 2011-2012). A total sample of 300 teachers with an equal sample size of 100 teachers from each block by using stratified random sampling technique was selected as per the explanation given in following chart.

Sample: A total sample of 300 teachers was selected by employing stratified random sampling technique. Thus, the sample comprised of 180 government and 120 private school teachers of the sampled area.

Thus, the sample comprised of 40 government and 33 private schools of the sampled area. An effort has been made to divide the sample into sub stratas like age, gender, status of job, academic qualification, marital status, and income.

The number of female teachers outnumbered the male teachers so equal representation to gender is the limitation of this part of the study. Sample included both permanent and contractual teachers.

Use of person's chi square and p-value: The data collected through structured and unstructured research questionnaire was processed and analysed. In the effort of processing the data, besides using percentages, the researcher had used person's chi square test result and $p$-value. The following parameters have been employed to analyse the data

The assumptions considered while analysing the primary data given in the Tables

Only the attributes having significant or highly significant relations with the different variables (i.e., questions) had been explained further. An attempt had been made to elucidate the statistical data quantitatively, as well as qualitatively in relation to the on interview, discussions and observations done by the researcher.

\section{Comparative Analysis of Satisfaction of Government and Private Primary School Teachers Towards School Administration}

\section{Work culture in school}

Organisation and its work culture directly or indirectly affect the job satisfaction its employees [16]. This study attempted to study the work culture in school. The Table 1 manifested that, all government school's respondents, affirmed that the work culture was pleasant in their school. However, not more than $83.3 \%$ private teachers stated that work culture was pleasant in their school (Table 2). The conversation with respondents also, brought forward that government school teachers favoured more that work culture was hospitable, cordial and amiable in school. Whereas private primary school teachers also feel that work culture was congenial in their school but some time they feel repulsive of their school work culture due to principal's high-handed leadership and for being considered as less important.

Even, the chi square results $\left(\mathrm{X}^{2}=32.143, \mathrm{p}>0.05\right)$ was found statistically highly significant, which revealed that there was variation in the proportion of responses among the government and private school respondents covered under study (Table 3). Therefore, it was reasonably concluded that government school teachers as compared to

\begin{tabular}{|c|c|c|}
\hline \multicolumn{2}{|c|}{ Literacy level of the blocks in Kaithal district } \\
\hline & Blocks & Literacy percentages \\
\hline 1 & Kaithal & 66 \\
\hline 2 & Pundri & 70 \\
\hline 3 & Rajond & 66 \\
\hline 4 & Kalayat & 64 \\
\hline 5 & Guhla & 65 \\
\hline 6 & Sivan & 67 \\
\hline
\end{tabular}

Source: Statistical and economic survey of Haryana, 2011-2012

Table 1: Sample selection.

\section{Chi Square Test}

Assumptions of Chi square test result in the present study

0.00 to 0.01

Above 0.02 up to 0.05 Significant

Table 2: Chi square test. 
private school teachers were feeling work culture as more pleasant in their schools.

\section{Perception of teachers regarding principal's behaviour}

Principal is the chief executive of school. Principal's leadership style and behaviour leaves direct impact on almost every dimension of school including teachers. Hence, principal should be gregarious and benign to teachers in school. The Table 3 showed that $98.3 \%$ government school teachers positively affirmed that principal was helpful to them. On the contrary, merely $70 \%$ respondents of private teachers approved the fact that principal was of helping nature (Table 3). The discussions lay down that government school teachers perceived it principal was friendly, cooperative, and cordial with them. On the other hand, private school teachers unconcealed during formal discussion that principal was not much cooperative. Principal's behaviour was dominating, rigid, harsh and authoritative in nature.

Even, the chi square results $\left(\mathrm{X}^{2}=51.162, \mathrm{p}<0.01\right)$ was found statistically highly significant, which revealed that there was variation in the proportion of responses among the government and private school respondents covered under study (Table 4). Eventually, it was deduced that government teachers as compared to private school teachers, perceived their principal as more helpful.

\section{Behaviour of colleagues/co-worker}

There is positive relationship between colleagues or co-worker behaviour and job satisfaction of employees in an organisation [17]. This study also made an effort to study the behaviour of colleagues in the school. The Table 5 manifested that, $95.6 \%$ government school teachers find colleagues as cooperative with them. In addition to this all the government M.Ed. and N.T.T teachers favoured that colleagues in their school were cooperative. Whereas, only $89.2 \%$ private teachers stated that colleagues were cooperative to them (Table 4). Furthermore, formal discussion with government school teachers acknowledged more that colleagues were accommodating, co adjuvant and reciprocal. Whereas private school respondents unveiled more as compared to government school respondents that colleagues were not much supportive, and accommodating.

The chi square test results $\left(\mathrm{X}^{2}=37.860, \mathrm{p}<0.01\right)$ was also found statistically highly significant, which revealed that there was variation in the proportion of responses among the government and private school respondents covered under study (Table 5). Hence, it was deduced that government teachers as compared to private school teachers, perceived their colleagues as more cooperative with them.

\section{Behaviour of administrative staff in school}

Administrative support indirectly impacts positively on teachers [18]. This study had made an effort to analyse the teacher's perception towards behaviour of administrative staff. The Table 5 showed that 93.9\% government schools advocated positively that administrative staff was cooperative with them. Contrastingly, only $79.2 \%$ private school teachers declared that administrative staff was cooperative with them (Table 6). The conversation with government school teachers also brought forward that teachers considered their administrative staff as congenial, benign and helpful. Whereas, private teachers viewed most of the administrative staff as less cooperative in nature.

Even the chi square results $\left(\mathrm{X}^{2}=16.529, \mathrm{p}<0.01\right)$ was found

\begin{tabular}{|c|c|c|c|c|c|c|c|c|c|c|}
\hline \multirow{2}{*}{\multicolumn{2}{|c|}{ Variables }} & \multirow{2}{*}{\multicolumn{2}{|c|}{ Yes }} & \multirow{2}{*}{\multicolumn{2}{|c|}{ No }} & \multirow{2}{*}{\multicolumn{2}{|c|}{ No comments }} & & \multirow{3}{*}{ Chi-square } & \multirow{3}{*}{ p-value } \\
\hline & & & & & & & & Total & & \\
\hline \multirow{2}{*}{ School type } & Government school & 180 & $100.00 \%$ & 0 & $0.00 \%$ & 0 & $0.00 \%$ & 180 & & \\
\hline & Private school & 100 & $83.30 \%$ & 15 & $12.50 \%$ & 5 & $4.20 \%$ & 120 & \multirow[t]{2}{*}{32.143} & \multirow[t]{2}{*}{$0.000^{* *}$} \\
\hline \multicolumn{2}{|c|}{ Total } & 280 & $93.30 \%$ & 15 & $5.00 \%$ & 5 & $1.70 \%$ & 300 & & \\
\hline
\end{tabular}

Table 3: Is there pleasant work culture in your school? Yes/No/No comments.

\begin{tabular}{|c|c|c|c|c|c|c|c|c|c|c|}
\hline \multirow{2}{*}{\multicolumn{2}{|c|}{ Variables }} & \multirow{2}{*}{\multicolumn{2}{|c|}{ Yes }} & \multirow{2}{*}{\multicolumn{2}{|c|}{ No }} & \multirow{2}{*}{\multicolumn{2}{|c|}{ No comments }} & \multirow{3}{*}{$\begin{array}{c}\text { Total } \\
180\end{array}$} & \multirow{3}{*}{ Chi-square } & \multirow{3}{*}{ p-value } \\
\hline & & & & & & & & & & \\
\hline \multirow{2}{*}{ School type } & Government School & 177 & $98.30 \%$ & 2 & $1.10 \%$ & 1 & $0.60 \%$ & & & \\
\hline & Private School & 84 & $70.00 \%$ & 28 & $23.30 \%$ & 8 & $6.70 \%$ & 120 & \multirow[t]{2}{*}{51.162} & \multirow[t]{2}{*}{$0.000^{* *}$} \\
\hline \multicolumn{2}{|c|}{ Total } & 261 & $87.00 \%$ & 30 & $10.00 \%$ & 9 & $3.00 \%$ & 300 & & \\
\hline
\end{tabular}

Table 4: Does the principal is helpful to you? Yes/No/No comments.

\begin{tabular}{|c|c|c|c|c|c|c|c|c|c|c|}
\hline \multirow{2}{*}{\multicolumn{2}{|c|}{ Variables }} & \multirow{2}{*}{\multicolumn{2}{|c|}{ Yes }} & \multirow{2}{*}{\multicolumn{2}{|c|}{ No }} & \multirow{2}{*}{\multicolumn{2}{|c|}{ No comments }} & & \multirow{3}{*}{ Chi-square } & \multirow{3}{*}{$p$-value } \\
\hline & & & & & & & & Total & & \\
\hline \multirow{2}{*}{ School type } & Government School & 172 & $95.60 \%$ & 8 & $4.40 \%$ & 0 & $0.00 \%$ & 180 & & \\
\hline & Private School & 84 & $70.00 \%$ & 34 & $28.30 \%$ & 2 & $1.70 \%$ & 120 & \multirow[t]{2}{*}{37.86} & \multirow[t]{2}{*}{$0.000^{* *}$} \\
\hline \multicolumn{2}{|c|}{ Total } & 256 & $85.30 \%$ & 42 & $14.00 \%$ & 2 & $0.70 \%$ & 300 & & \\
\hline
\end{tabular}

Source: Computed from primary data $p$-value $<0.01$ is highly significant denote**

Table 5: Does the colleagues were cooperative? Yes/No/No Comments.

\begin{tabular}{|c|c|c|c|c|c|c|c|c|c|c|}
\hline \multirow{2}{*}{\multicolumn{2}{|c|}{ Variables }} & \multirow{2}{*}{\multicolumn{2}{|c|}{ Yes }} & \multirow{2}{*}{\multicolumn{2}{|c|}{ No }} & \multirow{2}{*}{\multicolumn{2}{|c|}{ No comments }} & \multirow{3}{*}{$\begin{array}{c}\text { Total } \\
180\end{array}$} & \multirow{3}{*}{ Chi-square } & \multirow{2}{*}{ p-value } \\
\hline & & & & & & & & & & \\
\hline \multirow{2}{*}{ School type } & Government School & 169 & $93.90 \%$ & 11 & $6.10 \%$ & 0 & $0.00 \%$ & & & \multirow{3}{*}{$0.000^{* *}$} \\
\hline & Private School & 95 & $79.20 \%$ & 21 & $17.50 \%$ & 4 & $3.30 \%$ & 120 & \multirow[t]{2}{*}{16.529} & \\
\hline \multicolumn{2}{|c|}{ Total } & 264 & $88.00 \%$ & 32 & $10.70 \%$ & 4 & $1.30 \%$ & 300 & & \\
\hline
\end{tabular}

Source: Computed from primary data $p$-value $<0.01$ is highly significant denote* 
statistically highly significant, which revealed that there was variation in the proportion of responses among the government and private school respondents covered under study (Table 6). Therefore, it was inferred that government school teachers as compared to private school respondents stated positively that administrative staff was cooperative with them.

\section{Recognition in school}

Recognition at workplace plays a significant role in the satisfaction of an employee. Recognition refers to praise or acknowledgment of an employee's achievements [19]. Recognition can be in form of financial or non-financial i.e., praise or gestures [20]. This study made an effort to know whether teachers were satisfied with the recognition in school or not. The Table 6 indicated that $94 \%$ government school's respondents approved that they were getting enough recognition for their better performance and high achievements in school. On the other hand, barely $69.2 \%$ private teachers favored positively for the same (Table 7). During interactions with respondents it came forward that government school teachers as compared to private school teachers affirmed more that they were accorded and reimbursed enough for their better performance and high achievements in school.

Furthermore, the chi square results $\left(\mathrm{X}^{2}=14.554, \mathrm{p}<0.05\right)$ was found statistically highly significant, which revealed that there was variation in the proportion of responses among the government and private school respondents covered under study (Table 7). Hence conclusively, it was reasonably concluded that there was highly significant difference between government and government school respondents as compared to private school teachers declared it more positively that they were getting enough recognition for their better performance and high achievements in school.

\section{Job security}

The job security has a significant impact on employees. When employees feel secure about job, they feel positive relationship with the organisation [21]. The Table 8 revealed that $86.7 \%$ government school teachers affirmed positively to the fact that their job was secure in school. Nevertheless, not more than $49.2 \%$ private school teachers agreed that they were feeling job security in school (Table 7). During interaction with teachers it comes to light that government teacher as compared to private teachers felt more job certainty about their job. Private school teachers however articulated indefiteness, and uncertainty about their job.

When it comes to statistically differentiating the level of sense of security about their jobs between government and private school teachers (Figure 1); the chi square results $\left(\mathrm{X}^{2}=58.044\right.$, $\left.\mathrm{p}<0.01\right)$ was also found statistically highly significant, which revealed that there was variation in the proportion of responses among the government and private school respondents covered under study (Table 8). Hence, it was deduced reasonably that government teachers were experiencing more job security than private teachers in school.

\section{Proneness of teacher to leave the teaching job}

This study endeavoured to study the proneness of teachers to leave their job. The analysis of Table 9 manifested that $6.2 \%$ government school respondents stated that they were willing to leave the present job. Whereas, merely $29.2 \%$ private teachers stated that they would leave their job if they got opportunity to serve in some other organisation on same remuneration (Table 9). During interaction with government school respondents it comes to light that most of the teachers wanted to continue their present job. Furthermore, it was quite fulfilling, to be part of government sector, so they were not at all willing to change their present job. The discussions with private school teachers also disclosed that they were not willing to leave the present job as; it is difficult to adjust in new environment. However, the crux of discussion was that government school teachers were also less inclined to leave their job after getting an opportunity to serve in some other school on the same remuneration.

Even though, the chi square results $\left(\mathrm{X}^{2}=29.48, \mathrm{p}<0.01\right)$ was found

\begin{tabular}{|c|c|c|c|c|c|c|c|c|c|c|}
\hline \multirow{2}{*}{\multicolumn{2}{|c|}{ Variables }} & \multirow{2}{*}{\multicolumn{2}{|c|}{ Yes }} & \multirow{2}{*}{\multicolumn{2}{|c|}{ No }} & \multirow{2}{*}{\multicolumn{2}{|c|}{ No comments }} & & \multirow{3}{*}{ Chi-square } & \multirow{3}{*}{ p-value } \\
\hline & & & & & & & & Total & & \\
\hline \multirow{2}{*}{ School type } & Government School & 171 & $95.00 \%$ & 5 & $2.80 \%$ & 4 & $2.20 \%$ & 180 & & \\
\hline & Private School & 98 & $81.70 \%$ & 16 & $13.30 \%$ & 6 & $5.00 \%$ & 120 & \multirow[t]{2}{*}{14.554} & \multirow[t]{2}{*}{$0.001^{* *}$} \\
\hline \multicolumn{2}{|c|}{ Total } & 269 & $89.70 \%$ & 21 & $7.00 \%$ & 10 & $3.30 \%$ & 300 & & \\
\hline
\end{tabular}

Table 7: Do you get enough recognition and reward for your better performance and high achievements? Yes/No/ No Comments.

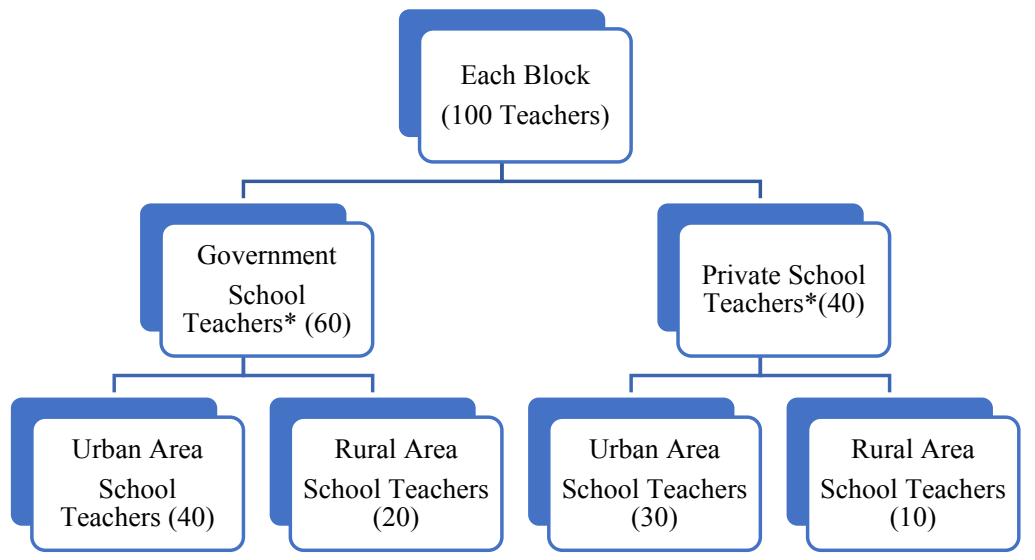

Government Schools are almost double the number of Private Schools

Figure 1: Government and private school teachers 


\begin{tabular}{|c|c|c|c|c|c|c|c|c|c|c|}
\hline \multirow{2}{*}{\multicolumn{2}{|c|}{ Variables }} & \multirow{2}{*}{\multicolumn{2}{|c|}{ Yes }} & \multirow{2}{*}{\multicolumn{2}{|c|}{ No }} & \multirow{2}{*}{\multicolumn{2}{|c|}{ No comments }} & & \multirow{2}{*}{ Chi-square } & \multirow{2}{*}{$p$-value } \\
\hline & & & & & & & & Total & & \\
\hline \multirow{3}{*}{ School type } & $\begin{array}{l}\text { Government } \\
\text { School }\end{array}$ & 156 & $86.70 \%$ & 23 & $12.80 \%$ & 1 & $0.60 \%$ & 180 & \multirow{4}{*}{58.044} & \multirow{4}{*}{$0.000^{* *}$} \\
\hline & Private School & 55 & $45.80 \%$ & 59 & $49.20 \%$ & 6 & $5.00 \%$ & 120 & & \\
\hline & $>15000$ & 152 & $82.20 \%$ & 29 & $15.70 \%$ & 4 & $2.20 \%$ & 185 & & \\
\hline \multicolumn{2}{|c|}{ Total } & 211 & $70.30 \%$ & 82 & $27.30 \%$ & 7 & $2.30 \%$ & 300 & & \\
\hline
\end{tabular}

Table 8: Do you feel your job is secure? Yes/No/No Comments.

\begin{tabular}{|c|c|c|c|c|c|c|c|c|c|c|}
\hline \multirow{2}{*}{\multicolumn{2}{|c|}{ Variables }} & \multirow{2}{*}{\multicolumn{2}{|c|}{ Yes }} & \multirow{2}{*}{\multicolumn{2}{|c|}{ No }} & \multirow{2}{*}{\multicolumn{2}{|c|}{ No comments }} & \multirow{3}{*}{\begin{tabular}{|c|} 
Total \\
180
\end{tabular}} & \multirow{3}{*}{ Chi-square } & \multirow{2}{*}{ p-value } \\
\hline & & & & & & & & & & \\
\hline \multirow{2}{*}{ School type } & Government School & 11 & $6.10 \%$ & 169 & $93.90 \%$ & 0 & $0.00 \%$ & & & \multirow{3}{*}{$0.000^{* *}$} \\
\hline & Private School & 35 & $29.20 \%$ & 85 & $70.80 \%$ & 0 & $0.00 \%$ & 120 & \multirow[t]{2}{*}{29.48} & \\
\hline \multicolumn{2}{|c|}{ Total } & 46 & $15.30 \%$ & 254 & $84.70 \%$ & 0 & $0.00 \%$ & 300 & & \\
\hline
\end{tabular}

Table 9: If you get an opportunity to serve in some other school on the same remuneration will you leave the present job? Yes/No/No Comments.

\begin{tabular}{|c|c|c|c|c|c|c|}
\hline \multirow{2}{*}{ Type of school } & & & & & \multirow{2}{*}{ Chi-square } & \multirow{2}{*}{ p-value } \\
\hline & Yes & No & No Comments & Total & & \\
\hline \multirow{2}{*}{ Govt. School } & 139 & 41 & 0 & 180 & \multirow{6}{*}{25.271} & \multirow{6}{*}{$0.000^{* *}$} \\
\hline & $77.20 \%$ & $22.80 \%$ & $0.00 \%$ & $100.00 \%$ & & \\
\hline \multirow{2}{*}{ Pvt. School } & 64 & 48 & 8 & 120 & & \\
\hline & $53.30 \%$ & $40.00 \%$ & $6.70 \%$ & $100.00 \%$ & & \\
\hline \multirow{2}{*}{ Total } & 203 & 89 & 8 & 300 & & \\
\hline & $67.70 \%$ & $29.70 \%$ & $2.70 \%$ & $100.00 \%$ & & \\
\hline
\end{tabular}

Source: Computed from Primary data, where $p$ - value $<0.01$ is highly significant denote ${ }^{\star *}$

Table 10: Do you think your salary is fair and at par with your academic qualifications, and work experience? Yes/No/No Comments

statistically highly significant, which revealed that there was variation in the proportion of responses among the government and private school respondents covered under study (Table 9). Hence, it was deduced reasonably that more of the private teachers as compared to government school teachers were willing to leave the present job after getting an opportunity to serve in some other school on the same remuneration.

\section{Teachers' perception regarding their salaries}

Wage, or salary is considered a significant reward to motivate the employees [22]. Table 9 showed that $77.2 \%$ government teachers favoured that their salary was fair and at par with their academic qualifications, and work experience. However, not more than $53.3 \%$ private school teachers approved that their salary was fair and at par with their academic qualifications (Table 10). The dialogue with respondents made known that considerably, most of the government school teachers feel that their salary was decent, virtuous and at par with academic qualifications and work experience. On the other hand, private school teachers interestingly brought forward that their salary was unsuitable and inappropriate and was not at all par with their academic qualifications and work experience. Private school teachers also exposed that they were living, precarious life due to meagre salaries. The added that even though proper salaries were specified by the governments for both government and private school's teachers, on the promise of confidentiality and anonymity they laid to open that they were provided with only Rs 3000 per month and they have to sign on document declaring that they were given salary of Rs 15000. Moreover, they were not even provided for paid holidays, may be its medical or maternity leave.

Even the chi square result $\left(\mathrm{X}^{2}=25.271, \mathrm{p}<0.00\right)$ was found highly significant, which revealed that there was variation in the proportion of responses among the government and private school respondents covered under study (Table 10). Thus, it can be concluded that government as compare to private school teachers felt more that their salary was fair and at par with their academic qualifications, and work experience.

\section{Communication}

The achievements and success of any educational institution depends largely upon principal's style of communication including on his/her efficiency, ability, skills and experience. The quality communication fosters the spirit and morale of teachers in the school [23]. Principal maintain academic and administrative relations through interaction and communication in school. When a principal communicates to teachers and other staff, it helps him in sharing his own ideas, assumptions with teachers and gaining awareness about the school related issues, resolving conflicts, maintaining and fostering motivation and morale of teachers. Table 11 showed that $98.3 \%$ private school teachers favoured that principal was communicating regularly with the staff in school. However, $93.9 \%$ government school teachers approved that principal in their school was communicating regularly with the staff in school (Table 11). During dialogue government school teachers brought to light that mostly principal discussed only school related problems. Formal means of communication (like letters, memos, circulars, notice etc) were used as a means of communication by principals in schools. Whereas, private school teachers expressed that principal takes personal initiatives to know about their problems. Principal, at times makes surprise visits in classrooms.

Even the chi square result $\left(\mathrm{X}^{2}=10.482, \mathrm{p}<0.05\right)$ was found significant, which revealed that there was variation in the proportion of responses among the government and private school respondents covered under study (Table 11). Therefore, it was inferred that private 
school teachers as compared to government school teachers favoured more that principal communicate frequently with them.

\section{Participation of teachers in decision making}

Decision making is the spirit of management and the democratic participation, interactions and communication holds key position in decision making. It also plays major role in planning, coordination and organizing any organisation. This study endeavoured to investigate the participation of teachers in decision making process in school. The Table 11 revealed that $93.3 \%$ government school teachers favoured that the principal was generally accepting their suggestions in good spirit. On the other side only $71.7 \%$ private school teacher favoured that principal accepted their suggestions in school (Table 12). During deliberations government school teachers brought to light that principal in their school was accepting suggestions in good predilections, propensity and temperament and consult staff while taking major decisions related to teachers. However, private school teachers disclosed that principal made decisions without any much consultation with staff. Most of the private school teachers felt fearful in criticizing the principal's decision. As principal was the supreme authority in school, so he/she had authority to detonate (dismiss) them without giving any reasonable cause for the same

Even the chi square result $\left(\mathrm{X}^{2}=26.044, \mathrm{p}<0.00\right)$ was found highly significant, which revealed that there was variation in the proportion of responses among the government and private school respondents covered under study (Table 12). Therefore, it was inferred that private school teachers as compared to government school teachers favoured more that principal in government schools were accepting suggestions in good spirit.

\section{Recruitments process}

Well qualified, committed staff contributes in the achievement of organizational goals. Table 13 revealed that $76.7 \%$ private school teachers avowed that recruitment procedure in school was fair. While, only $58.9 \%$ government school teacher admitted that recruitment in their school was fair (Table 13). During conversations with government school teachers it was unveiled that there was favouritism in recruitment procedure in schools. Other than politically powerful groups, factors like nepotism and casteism strongly intervened in recruitment procedure in schools. On the other hand, private school teachers favoured more that recruitments in their school was fair in their school.

Even the chi square result $\left(\mathrm{X}^{2}=11.491, \mathrm{p}<0.05\right)$ was found significant, which revealed that there was variation in the proportion of responses among the government and private school respondents covered under study (Table 13) Therefore, it was inferred that private school teachers as compared to government school teachers favoured more that recruitment procedure in their school was fair.

\section{Teacher's promotion}

Promotion is an incentive tool leads to positive changes like high salary, lesser supervision, and higher status. Promotion is a way of rewarding the employees for meeting the organizational goals. Promotion boosts self-worth and morale of the employees. It is essential to provide proper promotion to employees. Usually when there is

\begin{tabular}{|c|c|c|c|c|c|c|}
\hline \multirow{2}{*}{ Type of school } & & & & & \multirow{2}{*}{ Chi-square } & \multirow{2}{*}{ p-value } \\
\hline & Yes & No & No Comments & Total & & \\
\hline \multirow{2}{*}{ Govt. School } & 169 & 11 & 0 & 180 & \multirow{6}{*}{10.482} & \multirow{6}{*}{$0.005^{*}$} \\
\hline & $93.90 \%$ & $6.10 \%$ & $0.00 \%$ & $100.00 \%$ & & \\
\hline \multirow{2}{*}{ Pvt. School } & 118 & 0 & 2 & 120 & & \\
\hline & $98.30 \%$ & $0.00 \%$ & $1.70 \%$ & $100.00 \%$ & & \\
\hline \multirow{2}{*}{ Total } & 287 & 11 & 2 & 300 & & \\
\hline & $95.70 \%$ & $3.70 \%$ & $0.70 \%$ & $100.00 \%$ & & \\
\hline
\end{tabular}

Source: Computed from primary data, denote $p$-value $<0.05$ is significant denote*

Table 11: Does the principal communicate regularly with the staff? Yes/No/No Comments

\begin{tabular}{|c|c|c|c|c|c|c|}
\hline \multirow{2}{*}{ Type of school } & & & & & \multirow{2}{*}{ Chi-square } & \multirow{2}{*}{ p-value } \\
\hline & Yes & No & No Comments & Total & & \\
\hline \multirow{2}{*}{ Govt. School } & 168 & 9 & 3 & 180 & \multirow{6}{*}{26.044} & \multirow{6}{*}{$0.000^{* *}$} \\
\hline & $93.30 \%$ & $5.00 \%$ & $1.70 \%$ & $100.00 \%$ & & \\
\hline \multirow{2}{*}{ Pvt. School } & 86 & 26 & 8 & 120 & & \\
\hline & $71.70 \%$ & $21.70 \%$ & $6.70 \%$ & $100.00 \%$ & & \\
\hline \multirow{2}{*}{ Total } & 254 & 35 & 11 & 300 & & \\
\hline & $84.70 \%$ & $11.70 \%$ & $3.70 \%$ & $100.00 \%$ & & \\
\hline
\end{tabular}

Source: Computed from primary data $p$-value $>0.01$ is highly significant denote as ${ }^{* *}$

Table 12: Does principal generally accept your suggestions in good spirit? Yes/No/No Comments

\begin{tabular}{|c|c|c|c|c|c|c|}
\hline \multirow{2}{*}{ Type of school } & & & & & \multirow{2}{*}{ Chi-square } & \multirow{2}{*}{ p-value } \\
\hline & Yes & No & No Comments & Total & & \\
\hline \multirow{2}{*}{ Govt. School } & 106 & 71 & 3 & 180 & \multirow{6}{*}{11.491} & \multirow{6}{*}{$0.003^{* *}$} \\
\hline & $58.90 \%$ & $39.40 \%$ & $1.70 \%$ & $100.00 \%$ & & \\
\hline \multirow{2}{*}{ Pvt. School } & 92 & 25 & 3 & 120 & & \\
\hline & $76.70 \%$ & $20.80 \%$ & $2.50 \%$ & $100.00 \%$ & & \\
\hline \multirow{2}{*}{ Total } & 198 & 96 & 6 & 300 & & \\
\hline & $66.00 \%$ & $32.00 \%$ & $2.00 \%$ & $100.00 \%$ & & \\
\hline
\end{tabular}

Source: Computed from primary data, where $p$-value $<0.05$ is highly significant denote ${ }^{* *}$

Table 13: Does recruitment procedure in your school is fair? Yes/No/No Comments. 


\begin{tabular}{|c|c|c|c|c|c|c|}
\hline \multirow{2}{*}{ Type of school } & & & & & \multirow{2}{*}{ Chi-square } & \multirow{2}{*}{$p$-value } \\
\hline & Yes & No & No Comments & Total & & \\
\hline \multirow{2}{*}{ Govt. School } & 78 & 102 & 0 & 180 & \multirow{6}{*}{0} & \multirow{6}{*}{$1.000 \mathrm{~ns}$} \\
\hline & $43.30 \%$ & $56.70 \%$ & $0.00 \%$ & $100.00 \%$ & & \\
\hline \multirow{2}{*}{ Pvt. School } & 52 & 68 & 0 & 120 & & \\
\hline & $43.30 \%$ & $56.70 \%$ & $0.00 \%$ & $100.00 \%$ & & \\
\hline \multirow{2}{*}{ Total } & 130 & 170 & 0 & 300 & & \\
\hline & $43.30 \%$ & $56.70 \%$ & $0.00 \%$ & $100.00 \%$ & & \\
\hline
\end{tabular}

Table 14: Did you get any promotion? Yes/No/No Comments.

sufficient scope for promotion, workers get job satisfaction [24]. When the management does not care to give promotion to capable and efficient workers there is an increased feeling of frustration amongst staff [25]. The Table 14 revealed that $43.3 \%$ government teachers approved that they got promotion interim service. It was also interesting to find that equally, $43.3 \%$ private school teachers accepted that they got promotion in school (Table 14). However, it was attention grabbing that regardless of the fact teachers belonged to government or private schools, most of the primary school teachers were not promoted during their services. When the researcher inquired about it, most of teachers ratified that they were not promoted during the service. Moreover, government school teachers outraged their anger towards government regarding promotion. However, some of the teachers expressed that few senior teachers were made head teachers after their prolonged service.

Even the chi square result $\left(\mathrm{X}^{2}=0.000, \mathrm{p}<0.05\right)$ was found nonsignificant that there was no variation in the proportion of responses among the government and private school respondents covered under study (Table 14) Therefore, it was inferred that regardless of the fact teachers belonged to government or private school most of the teachers did not get any promotion in schools.

\section{Results and Discussion}

\section{Major findings}

1. Government school teachers as compared to private school teachers were feeling work culture as more pleasant in their schools.

2. Government teachers as compared to private school teachers, perceived their principal as more helpful.

3. Government teachers as compared to private school teachers, perceived their colleagues as more cooperative with them.

4. Government school teachers as compared to private school respondents stated more positively that administrative staff was cooperative with them.

5. Government school respondents as compared to private school teachers declared it more positively that they were getting enough recognition for their better performance and high achievements in school.

6. Government teachers were experiencing more job security than private teachers in school.

7. Private teachers as compared to government school teachers were more willing to leave the present job after getting an opportunity to serve in some other school on the same remuneration.

8. Government as compare to private school teachers felt more that their salary was fair and at par with their academic qualifications, and work experience.

9. Private school teachers as compared to government school teachers affirmed more that principal communicate frequently with them.
10. Private school teachers as compared to government school teachers approved more that principal in government schools were accepting suggestions in good spirit.

11. Private school teachers as compared to government school teachers favoured more that recruitment procedure in their school was fair.

12. Regardless of the fact teachers belonged to government or private school most of the teachers did not get any promotion in schools.

\section{Conclusion}

No doubt there are several policies formulated by governments, improved the condition of teachers. Increase in salary, standardization of teacher pupil ratios, teacher's training etc. Still there are ineffective and improper administrative policies, which need to be modified. Teachers, especially private primary school teacher today are suffering from low self-esteemed and low morale so there is an urgent need to pay attention to teachers in schools. Promotion policy of teachers, leadership, measures for benefits for government contractual teachers are major area of concern for government school teachers. Whereas, the private school teachers are suffering with a different issue like poor salaries, undemocratic leaderships, mistreatments by high authorities, job distress, job insecurities etc. Salaries in private schools are meager and considerably much lower than that in government schools. Even the private school teachers are paid much less than their competency.

All these factors lead to teacher's job dissatisfaction. Job dissatisfaction further results to high turnover and absenteeism rate of teachers in schools. It is the responsibility of state government, educational administrator and policy makers to invest time, efforts and make measures to enhance level of job satisfaction of teachers. For the achievement of primary education goals, there teachers should be given adequate concern in policy making. In addition to this, proper implementation and regular monitoring of those policies is equally as important as to make those policies.

\section{References}

1. Moehlman A (1951) School administration. Bosten: Houghton Mifflin. p. 83.

2. Jesse SB (1959) The Nature of the administrative process. New York: mcrawHill, US. p. 4.

3. Grayson K (1964) The forty fifth yearbook, Pt. II Chicago; University of Chicago US. Press: 2.

4. Paul MR (1946) Principles of school administration, New York: McGraw-Hill, US.

5. David K, Robert KL (1966) The social psychology of organization, John Wiley and Sons, Inc. New York, London, US. p. 1.

6. Schuster FE (1978) Personal administration: human resources management key to the future," New Delhi; Allied Publisher, India. pp. 65-68.

7. Pestonjee DM (1973) Organisational structures and job attitudes, New Delhi India. pp. 20- 21

8. Gurpreet R (2005) The relationship between work attitudes and work performance. Manag Labor Studies 30: 315-321. 
Citation: Sheokand U (2017) An Elucidation of School Administration and Work Culture of Schools in Relation to Teacher's Satisfaction. Review Pub Administration Manag 5: 217. doi:10.4172/2315-7844.1000217

Page 8 of 8

9. Steinhaus CS, Perry JL (1996) Organisational commitment: Does sector matter? Public Product Manage Rev 19: 278-288.

10. Cranny CJ, Smith PC, Stone EF (1992) Job satisfaction: how people feel about their jobs and how it affects their performance, New York: Lexington Books, US.

11. Spector PE (1997) Job Satisfaction: Application, assessment, causes and consequences, Thousand Oaks, CA.

12. Hoppock R (1935) Job satisfaction, Harper and Brothers, New York, US. p. 47.

13. Locke EA (1976) The nature and causes of job satisfaction, in m. dynnetle (eds)", Handbook of Industrial and Organizational Psychology; Rand McNally, Chicago, US. p. 1304.

14. Brin D, Andrew J (1988) The Practice of Supervision; Universal Bookstall, New Delhi, India. p. 58.

15. Graham GH (1982) Understanding human relations: The individual, organizations, and management, science research associates, Chicago, US Inc: 68.

16. Morse NC (1953) Satisfaction in the white-callor job, Ann Arob MI: University of Michigan Survey Research Center, US.

17. Riordan CM, Griffeth RW (1995) The opportunity for friendship in the workplace:
An underexplored construct. Journal of Bus psychol 10: 141-154.

18. Brunetti GJ (2006) Resilience under fire: Perspectives on the work of experienced, inner city high school teachers in the United States. J Teach Teach Edu 22: 812-825.

19. Gostick A, Elton C (2007) The Daily career principle: 365 ways to enhance your career and life, New York: Simon and Schuster.

20. DeCenzo DA, Robbins SP (2010) Fundamentals of human resource management (10th edn), NJ: John Wiley and sons, Hoboken, US Inc.

21. Poza SA (2000) Wellbeing at work: A cross-national analysis of the levels and determinants of job satisfaction. J Soc Econ 29: 517-538.

22. Oshagbemi $\mathrm{T}(2000)$ Correlates of pay satisfaction in higher education. Int $\mathrm{J}$ Edu Manage 14: 31-39.

23. Fisher RJ, Maltz E, Jaworski BJ (1997) Enhancing communication between marketing and engineering: The moderating role of relative functional identification. J Mark 61: 54-70.

24. Watsonand G, Seidman M (1941) Dissatisfaction in work. J Soc Psychol 13 183-186.

25. Das G (1999) Industrial Psychology; King Books Co, NaiSarak, New Delhi, India. p. 126. 